FINANCIAL: Jurnal Akuntansi

Published by Program Studi Akuntansi STIE Sultan Agung Volume 7-Nomor 2, Desember 2021, (HIm 198-206)

ISSN-P: 2502-4574, ISSN-E: 2686-2581

Available online at: https://financial.ac.id/index.php/financial

\title{
FACTORS AFFECTING ACCOUNTING CONSERVATISM FOR FOOD AND BEVERAGE SUB SECTOR BETWEEN 2016-2020 PERIOD
}

\author{
Novi Nugrahani ${ }^{1{ }^{*}}$, Fita Setiati $^{2)}$, Siti Amerieska ${ }^{3)}$ \\ ${ }^{1,2,3}$ Management Accounting Study Program, State Polytechnic of Malang, Jl. Soekarno Hatta No.9, \\ Jatimulyo, Kec. Lowokwaru, Kota Malang, Jawa Timur 65141, Indonesia \\ E-mail: ${ }^{1}$ novinugrahani@polinema.ac.id, ${ }^{2}$ fita.setiati@polinema.ac.id, ${ }^{3}$ siti.amerieska@ polinema.ac.id
}

\begin{abstract}
It is challenging that food and beverage sub-sector is growing rapidly these days. As a matter of fact, there are various variables affecting the accounting conservatism in food and beverage industry. The purpose of this study is to determine simultaneously and partially the factors that influence accounting conservatism. These factors are debt covenant, company growth, financial distress, litigation risk, and political costs. The population of this study is the food and beverage sub-sector companies listed on the Indonesia Stock Exchange (IDX) for the 20162020 period. This study applied purposive sampling technique in selecting the sample of this study. This study used multiple regression analysis using SPSS software. The partial test showed that debt covenant and financial distress had a significant effect on accounting conservatism. Besides, the variables of company growth, financial distress, and political costs had no significant effect on accounting conservatism. Simultaneous test results showed that there was a significant influence of debt covenant, company growth, financial distress, litigation risk, and political costs on accounting conservatism. Further research is encouraged to be conducted on companies listed on IDX from various sub-sectors other than food and beverage to broaden the coverage. Also, it would be interesting to observe other factors affecting accounting conservatism through other periods to compare the results.
\end{abstract}

Keywords: accounting conservatism, food and beverage sub-sector, 2016-2020 period

Article History: Received: 8 Okt 2021 Revised: 17 Nov 2021 Accepted: 27 Nov 2021 


\section{INTRODUCTION}

Companies which greatly contribute to tax payment in Indonesian context is the manufacturing companies in food and beverage sub-sector. Therefore, it is challenging to discover the factors affecting the accounting conservatism as we can find out many aspects to learn from this aspect alone. Conservatism tends to slow down the income recognition and fasten cost so that the reported profit tends to be lower. Studies related to conservatism have been conducted by researchers with various findings. One of the factors affecting accounting conservatism is debt covenant.

A high debt covenant gives incentive for companies to adjust their profit which leads to the more conservative financial report. This is reflected from the findings of a previous research (Noviantari \& Ratnadi, 2015). However, this is contradictory to the statement of another research which showed that if the debt covenant is low, companies will be cautious in reporting (Agustina et al., 2015).

The next variable is company growth which becomes a significant hope from all parties in the company (they are the company management and external companies such as investors and creditors). In this study, company growth was measured from the sale growth. According to a study, sale growth positively affected conservatism (Andreas et al., 2017).

Regarding the variable of financial distress, the previous research carried out showed that financial distress negatively affected conservative accounting (Noviantari \& Ratnadi, 2015). Another researcher discovered that financial distress did not affect accounting conservatism (Putri, 2017). About the variable of litigation risk, another researcher showed that litigation risk positively affected accounting conservatism (Zuhriyah, 2017). However, this finding was not in line with the other research conducted which believed that litigation risk did not affect accounting conservatism (Putri, 2017). The next variable is political cost. In another previous research, it was showed that political cost affected accounting conservatism (Iskandar, 2016).

Based on the background theory of the study and the findings from previous research, the formulated research problems include whether or not there is any influence of debt covenant cost, company growth, financial distress, litigation risk, and political cost towards accounting conservatism at food and beverage companies listed on the Indonesian Stock Exchange from 2016 to 2020 .

\section{THEORETICAL REVIEW Accounting Conservatism}

Conservatism is a concept of taking the note of expense and liabilities as early as possible even though the result is not absolute and only taking the note of income and asset only when they will surely be gained. Accounting conservatism helps to avoid the manager's opportunistic behavior in the contract, where it will be used, report, financial data, as media, contract (Savitri, 2016). Therefore, when a situation which can cause loss, cost, and debt occurred, the loss, cost, and debt have to be immediately recognized (Rohminatin, 2016).

Conservatism principles are the concept which recognizes expense and liabilities as soon as possible even though there is uncertainty regarding the result; but it only recognizes income and asset when they are believed to be gained. Accounting conservatism is helpful in avoiding manager's opportunistic behaviors related to 
contracts which use financial report as the contract media (Savitri, 2016). Consequently, if there is a condition which cause loss, cost, and debt, those loss, cost, and debt have to be immediately recognized (Rohminatin, 2016). It was suggested to measure accounting conservatism by using conv_accrual (Savitri, 2016; Zhang, 2008). The used formula is showed as follows:

\section{CCONNAC $=$}

Non operating accrual/total aset $\mathrm{x}(-1)$

Description:

Nonoperating Accrual = Operating accrual - Account Receivable - Inventory Prepaid expense + Account Payable + Taxes Payable

Operating Accrual $=$ Net Income + Depreciation - Net Operating Cash Flow

Net Operating Cash Flow = gap between the coming cash and the issued cash from operational activity

In his research, Zhang multiplied conv_accrual with -1 in order to help analyzing where the higher the conv_accrual value showed the higher conservatism implementation.

\section{Debt Covenant}

Debt covenant is debt contract which can be measured by leverage. Leverage is the capability size of company asset to pay the company's liabilities. Using debt covenant, company will receive credit from creditors. Because creditors pay attention to the given information, managers have to cautiously recognize the value of each item in the financial report. Therefore, debt covenant can affect accounting conservatism. This recognition is in line with previous research's findings (Noviantari \& Ratnadi, 2015; Putri, 2017).

\section{Company Growth}

Business growth is an important hope expected by management, investor, and creditor. Company growth can be measured from the sale growth, profit growth, Price to Book Value (PBV) growth, and asset growth. In this study, the company growth was measured from the sale growth because the sale growth would affect the company accrual level such as supply, accounts receivable, and etc. The high sale growth tends to increase the market expectation for the future cash flow and it affects conservatism. Company growth in the future showed that the company has gained huge profit. The higher income growth showed that company is more conservative. This is supported by the previous research which stated that sale growth positively affected conservatism (Andreas et al., 2017).

\section{Financial Distress}

Financial distress is a phase where the financial condition is decreasing before the occurrence of bankruptcy and liquidation (Fahmi, 2017). This study applied the method of Altman Z-Score ratio 5 (for Manufacture Company) with the proxy as follows:

$$
\begin{gathered}
\mathrm{Z}=1.2(\mathrm{X} 1)+1.4(\mathrm{X} 2)+3.3(\mathrm{X} 3)+0.6 \\
(\mathrm{X} 4)+0.999(\mathrm{X} 5)
\end{gathered}
$$

$\mathrm{Z}=$ Bankruptcy index value

$\mathrm{X} 1=$ Working capital (current activaliabilities)/ Total activa

$\mathrm{X} 2=$ Retained earnings/Activa capital

$\mathrm{X} 3=$ EBIT/Activa Capital

$\mathrm{X} 4$ = Market value of equity to book/Total debt

X5 $=$ Sale/Total activa 
The indicators for the function above are:

\begin{tabular}{|r|l|l|}
\hline No. & \multicolumn{1}{|c|}{ Criteria } & \multicolumn{1}{c|}{ Description } \\
\hline 1. & $\mathrm{Z}<1.81$ & Bankruptcy Zone \\
\hline 2. & $1.81<\mathrm{Z}<$ & Grev/Doubt Zone \\
\hline 3. & $\mathrm{Z} \quad 99$ & Safe/Not Bankrupt \\
\hline
\end{tabular}

Source: Altman, 1968

\section{Litigation Risk}

Litigation risk is risk which the stakeholders think as non-profitable because the financial information does not match the company requirement (Maux, J. L., Francoeur, 2014). From another point of view, it was explained that the Debt to Equity Ratio (DER) could be used to measure litigation risk (Zuhriyah, 2017). The higher the DER level, the bigger a company's litigation risk. The following is the proxy of litigation risk:

$$
\text { DER }=\frac{\text { Total Debt }}{\text { Total Capital/Total Equity }}
$$

\section{Political Cost}

According to the law applies, when company and government have the contradictory power to transfer assets from company to society, there will be political cost (Iskandar, 2016). The implementation of income decreasing accounting policy by doing profit suspension is carried out so that the company seems to be having performance decreasing. This kind of profit suspension is conservative. When measuring the political cost, this study implemented size measurement standard (company size). Company size is a size which can classify how big or how small a company is and display the company asset. This asset is often seen and may be interesting for the company's stakeholders. The size measurement applies the following formula:

$$
\text { Size }=\text { Ln Total Asset }
$$

Copyright (C) 2021, FINANCIAL: Jurnal Akuntansi

\section{METHOD}

In this study, the population used was non-financial companies listed on Indonesia Stock Exchange from 2016 to 2020. The sample collection was done using purposive sampling method. The sample criteria are as follow: (1) run at the sector of food and beverage which are listed on Indonesia Stock Exchange from 2016 to 2020, (2) companies publish financial report ending at December $31^{\text {st }}$ in the form of rupiah currency and has been audited. From the two criteria, there were 10 companies used as the sample. The analysis implemented was multiple linier regression. Data were processed by using SPSS.

\section{ANALYSIS AND DISCUSSION Descriptive Analysis}

The description result of debt covenant (X1) got the average of 0.268 and the standard deviation was 0.147. Company growth (X2) got the average of 0.058 and the standard deviation was 0.102. Financial distress (X3) got the average of 7.288 and the standard deviation was 4.556. Litigation risk (X4) got the average of 0.676 and the standard deviation was 0.430 . Political cost (X5) got the average of 29.156 and the standard deviation was 1.623. The accounting conservatism (Y) got the average of -0.531 and the standard deviation was 0.122 .

\section{Classic Assumption Tests Normality Test}

The result of normal PP chart use to test the residual normality showed that the plot dots coincided with diagonal so that the residual followed the normal distribution dan fulfilled the normality assumption. The result of residual normality test and KolmogorovSmirnov test gained the significance score of 
0.985 so that the significance score was bigger than $0.05(\mathrm{p}>0.05)$ which meant that the residual

\section{Heteroscedasticity Test}

It was known from the Scatter chart that ZPRED and SRESID plots showed that those plot dots were randomly spread and did not form certain pattern so that the heteroscedasticity assumption was fulfilled. The result of heteroscedasticity test using Glejser test got the significance value of debt covenant (X1) variable was 0.401 , the company growth (X2) variable was 0.272 , the financial distress (X3) variable was 0.061 , the litigation risk (X4) variable was 0.906 , and the political cost (X5) variable was 0.745 so that the significance value of each free variable was more than 0.05 $(p>0.05)$ which means that the heteroscedasticity assumption was fulfilled.

\section{Multicollinearity Test}

The VIF value of debt covenant (X1) variable was 1.493 , the company growth (X2) variable was 1.129 , the financial distress (X3) variable was 1.389, the litigation risk (X4) variable was 1.386, and the political cost (X5) variable was 1.243 so that the VIF value of each free variable was less than 10 (VIF < 10) which means that the multicollinearity assumption was fulfilled.

\section{Autocorrelation Test}

The value of Durbin Watson reached the range of dU score and 4-dU score (dU < DW < 4-dU) which meant that the autocorrelation assumption was fulfilled.

\section{Analysis of Multiple Linier Regression}

\begin{tabular}{|c|c|c|c|c|c|}
\hline \multirow[t]{2}{*}{ Model } & \multicolumn{2}{|c|}{$\begin{array}{c}\text { Unstandardized } \\
\text { Coefficients }\end{array}$} & \multirow{2}{*}{\begin{tabular}{|c|}
$\begin{array}{c}\text { Standardized } \\
\text { Coefficients }\end{array}$ \\
Beta
\end{tabular}} & \multirow[t]{2}{*}{$\mathrm{T}$} & \multirow[t]{2}{*}{ Sig. } \\
\hline & B & $\begin{array}{l}\text { Std. } \\
\text { Error }\end{array}$ & & & \\
\hline (Constant) & -.293 & .291 & & -1.007 & .319 \\
\hline $\begin{array}{l}\text { Debt } \\
\text { Covenant }\end{array}$ & -.273 & .115 & -.329 & -2.373 & .022 \\
\hline $\begin{array}{l}\text { Company } \\
\text { Growth }\end{array}$ & .006 & .144 & .005 & .041 & .967 \\
\hline $\begin{array}{l}\text { Financial } \\
\text { Distress }\end{array}$ & .006 & .004 & .207 & 1.545 & .129 \\
\hline $\begin{array}{l}\text { Litigation } \\
\text { Risk }\end{array}$ & -.084 & .038 & -.297 & -2.225 & .031 \\
\hline $\begin{array}{l}\text { Political } \\
\text { Cost }\end{array}$ & -.005 & .009 & -.068 & -.537 & .594 \\
\hline
\end{tabular}

Source: Processed Research Data (2021)

The equation of multiple linier regression is presented as follow:

$$
\begin{gathered}
y=a+b 1 \times 1+b 2 \times 2+b 3 \times 3+b 4 \times 4+b 5 \\
x 5+e \\
y=-0.293-0.273 \times 1+0.006 \times 2+0.006 \times 3 \\
-0.084 \times 4-0.005 \times 5+e
\end{gathered}
$$

From the equation, it can be explained that the constant value (a) was 0.293 which showed that without the influence of debt covenant (X1), company growth (X2), financial distress (X3), litigation risk (X4), and political cost (X5), the accounting conservatism value $(\mathrm{Y})$ was 0.293 .

Next implication was that the coefficient value of debt covenant (X1) was 0.273 which showed the negative effect of debt covenant (X1) towards accounting conservatism (Y) which meant each the value increase of debt covenant (X1) would affect the prediction value increase of conservatism (Y). This means that the higher the debt covenant (X1) is, the lower the accounting conservatism (Y) will be.

Also, the coefficient of company growth (X2) was 0.006 which showed that 
there was positive influence of company growth (X2) towards accounting conservatism (Y) which means that each value increase of company growth (X2) would affect towards the prediction value increase of accounting conservatism (Y). This means that the higher the company growth (X2), the higher accounting conservatism (Y) will be.

In addition, the coefficient of financial distress (X3) was 0.006 which showed that there was positive influence of financial distress (X3) towards accounting conservatism (Y), it means that each value increase of financial distress (X3) will affect towards the prediction value increase of accounting conservatism (Y). This means that the higher the financial distress (X3), the higher the accounting conservatism (Y).

Next, the coefficient of litigation risk (X4) was -0.084 which showed that there was negative influence of litigation risk (X4) towards accounting conservatism (Y), which means that each value increase of litigation risk (X4) will affect the prediction value increase of accounting conservatism (Y). This means that the higher litigation risk (X4), the lower the accounting conservatism (Y) will be.

Meanwhile, the I coefficient value (X5) was -0.005 which showed that there was negative influence of political cost (X5) towards accounting conservatism (Y), it means that each value increase of political cost (X5) will affect the prediction value increase of accounting conservatism (Y). This means that the higher political cost (X5), the lower accounting conservatism (Y) will be.

\section{Hypothesis Testing}

Simultaneous Test (F-test)
The result of simultaneous test gained the $\mathrm{F}$ value (6.720) was more than the F table (2.427) or the significance value $(0.000)$ was less than alpha (0.050) which showed that there was significant influence of debt covenant (X1), company growth (X2), financial distress (X3), litigation risk (X4), and political cost (X5) on accounting conservatism (Y) simultaneously.

Table 2. Result of Simultaneous Test

\begin{tabular}{|l|l|l|l|l|l|}
\hline Model & $\begin{array}{l}\text { Sum } \\
\text { of } \\
\text { Squares }\end{array}$ & Df & $\begin{array}{l}\text { Mean } \\
\text { Square }\end{array}$ & F & Sig. \\
\hline Regression & .315 & 5 & .063 & 6.720 & $.000^{\mathrm{b}}$ \\
Residual & .412 & 44 & .009 & & \\
Total & .727 & 49 & & & \\
\hline
\end{tabular}

Source: Processed Research Data (2021)

Determination Coefficient $\left(\mathrm{R}^{2}\right)$

From the result of determination coefficient, it was gained that the R Square value was 0.433 which meant that the effect on accounting conservatism variable (Y) which was explained by the variables of debt covenant (X1), company growth (X2), financial distress (X3), litigation risk (X4), and political cost (X5) was 43.3 percent while the rest was explained by other factors.

Table 3. Result of Determination Coefficient

\begin{tabular}{|l|l|l|l|l|}
\hline Model & $\mathrm{R}$ & $\begin{array}{l}\mathrm{R} \\
\text { Square }\end{array}$ & $\begin{array}{l}\text { Adjusted R } \\
\text { Square }\end{array}$ & $\begin{array}{l}\text { Std. Error } \\
\text { of the } \\
\text { Estimate }\end{array}$ \\
\hline 1 & $.658^{\mathrm{a}}$ & .433 & .369 & .096790 \\
\hline
\end{tabular}

Source: Processed Research Data (2021)

Partial Test (t-test)

The following is the test result presentation of partial influence by using ttest. 
Table 4. Result of Partial Test

\begin{tabular}{|l|l|l|}
\hline \multicolumn{1}{|c|}{ Model } & \multicolumn{1}{|c|}{$\mathrm{T}$} & \multicolumn{1}{c|}{ Sig. } \\
& & \\
\hline (Constant) & -1.007 & .319 \\
Debt Covenant & -2.373 & .022 \\
Company Growth & .041 & .967 \\
1 Financial Distress & 1.545 & .129 \\
Litigation Risk & -2.225 & .031 \\
Political Cost & -.537 & .594 \\
\hline
\end{tabular}

Source: Processed Research Data (2021)

There are several points that can be implied from the results of partial test. Partial test between debt covenant variable (X1) towards accounting conservatism variable (Y) obtained the $t$ value (2.373) was more than $t$ table (2.015) or the significance value (0.022) was less than alpha $(0.050)$ so that there was a significant effect of debt covenant variable (X1) towards accounting conservatism $(\mathrm{Y})$.

The next thing is that partial test between company growth variable (X2) towards accounting conservatism variable (Y) obtained the $t$ value $(0.041)$ was less than $\mathrm{t}$ table (2.015) or the significance value (0.967) was more than alpha $(0.050)$ so that there was no significant effect of company growth variable (X2) towards accounting conservatism $(\mathrm{Y})$

Also, partial test between financial distress variable (X3) towards accounting conservatism variable $(\mathrm{Y})$ obtained the $\mathrm{t}$ value (1.545) was less than t table (2.015) or the significance value $(0.129)$ was more than alpha (0.050) so that there was no significant effect of financial distress variable (X3) towards accounting conservatism (Y).

In addition, partial test between litigation risk variable (X4) towards accounting conservatism variable (Y) obtained the $\mathrm{t}$ value (2.225) was more than $\mathrm{t}$ table (2.015) or the significance value (0.031) was less than alpha (0.050) so that there was a significant effect of litigation risk variable (X4) towards accounting conservatism (Y).

Also, partial test between political cost variable (X5) towards accounting conservatism variable ( $\mathrm{Y}$ ) obtained the $\mathrm{t}$ value (0.537) was less than $t$ table (2.015) or the significance value (0.594) was more than alpha (0.050) so that there was no significant effect of political cost variable (X5) towards accounting conservatism (Y).

\section{Discussion}

Debt covenant which was measured using leverage had significant effects on accounting endurance. This showed that companies with high debt level tended to be more conservative. Because the loan lenders wanted their money to be safe, they kept trying to examine how the business run which referred to the management following conservative principles. These findings are in line with previous researchers who pronounced that leverage influences accounting conservatism (Noviantari \& Ratnadi, 2015). Company growth did not affect conservatism principles. This is in line with the previous research (Saputri, 2013). Financial distress did not affect the implementation of accounting conservatism which is in line with a previous study (Abdurrahman \& Ermawati, 2019). Even though in the middle of Covid-19 pandemic, food and beverage companies kept their fine performance each year because the traded commodity was the main necessity of the society. Therefore, company management decreased the implementation of accounting conseratism. Litigation risk had significant effect on accounting conservatism. This result is in line with the research carried out 
before (Andani, M. Nurhayati, 2021). Therefore, the high company's profit led to lower litigation risk and liabilities possibility. It pushed the company to be more cautious by not presenting too much profit and fastened the company's debt recognition. Political cost would not affect accounting conservatism may be caused by the fact that food and beverage companies were dominated by big companies which always fulfilled the government policy so that it would not disturb the implementation of conservatism at the company.

\section{CONCLUSION AND SUGGESTION}

Debt covenant and litigation risk significantly affected accounting conservatism. While company growth, financial distress, and political cost variables did not significantly affect accounting conservatism. Simultaneous test showed that there was significant influence of debt covenant, company growth, financial distress, litigation risk, and political cost on accounting conservatism.

The research findings are expected to be the light for next researchers to conduct further study regarding factors affecting accounting conservatism on various areas of companies other than food and beverage subsector. The findings of this study are also expected to be helpful for the investors so that they know more about companies' condition especially regarding the factors affecting accounting conservatism.

\section{REFERENCES}

Abdurrahman, M. A., \& Ermawati, W. J. (2018). Pengaruh Leverage, Financial Distress dan Profitabilitas terhadap Konservatisme Akuntansi pada Perusahaan Pertambangan di Indonesia Tahun 2013-2017. Jurnal Manajemen dan Organisasi, Vol. 9 No. 3. 9(3).

Copyright (C) 2021, FINANCIAL: Jurnal Akuntansi
Agustina et al (2015). Analisa FaktorFaktor Yang Mempengaruhi Penerapan Konservatisme Akuntansi Pada Perusahaan Manufaktur Yang Terdaftar di Bursa Efek Indonesia. Simposium Nasional Akuntansi 18.

Altman, E. I. (1968). Financial Ratios, Discriminant Analysis and the Prediction of Corporate Bankcrupty. The Journal of Finance. Vol 23 No 4.

Andani, M., \& Nurhayati, N. (2021). Pengaruh Ukuran Perusahaan, Financial Distress, Resiko Litigasi Terhadap Konservatisme Akuntansi. Dinamika Ekonomi Jurnal Ekonomi Dan Bisnis, 14(1), 206-224. Diambil dari https://stienasypb.ac.id/jurnal/index.php/jdeb/article/ view/322.

Andreas, H. H., Ardeni, A., \& Nugroho, P. I. (2017). Konservatisme Akuntansi di Indonesia. Jurnal Ekonomi dan Bisnis. Vol. 20, No. 1. ISSN: 1979 6471.

Fahmi, Irham. (2017). Analisis Laporan

Keuangan, Alfabeta, Bandung.

Iskandar, O. R. (2019). Pengaruh Debt Covenant, Bonus Plan, dan Political Cost Terhadap Konservatisme Akuntansi. Jurnal Ekonomi, Manajemen, Akuntansi Vol. 22 No. 6.

Maux, J. L., \& Francoeur, C. (2014). Block

Premia, Risk, and Shareholder Protection.

Noviantari, N., \& Ratnadi, N. (2015). Pengaruh Financial Distress, Ukuran Perusahaan, dan Leverage Pada Konservatisme Akuntansi. E-Jurnal Akuntansi, 11(3), 646-660.

Putri, A. G. (2017). Pengaruh Kesulitan Keuangan Risiko Litigasi dan Leverage Terhadap Konservatisme Akuntansi. JOM Fekon, Vol.4 No.1. 37-48.

Rohminatin. (2016). Faktor-Faktor yang Mempengaruhi Penerapan Konservatisme Akuntansi (Studi Pada Manufaktur yang terdaftar di BEI. Jurnal Ilmiah Infotek, 65 - 74 . 
Saputri, Y. (2013). Faktor-Faktor Yang Mempengaruhi Pilihan Perusahaan Terhadap Konservatisme Akuntansi. Accounting Analysis Journal, 2(2). https://doi.org/10.15294/aaj.v2i2.1576

Savitri, E. (2016). Konservatisme Akuntansi Cara Pengukuran, Tinjauan, Empiris, dan Faktor-faktor yang mempengaruhinya. Yogyakarta: Pustaka Sahila Yogyakarta.

Zhang, J. (2007). The Contracting Benefits of Accounting Conservatism to Lenders dan Borrowers. B.S Finance and Accounting, $2-54$.

Zuhriyah, E. A. (2017). Konvergensi IFRS, Leverage, Financial Distress,Litigation Dalam Kaitan dengan Konservatisme Akuntansi. Jurnal Prosiding Akuntansi, 213-220 